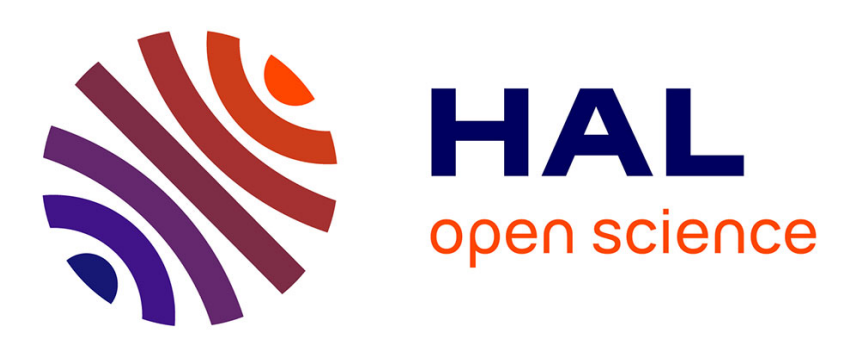

\title{
The Single-Step Method of RNA Purification Applied to Leptospira
}

Crispin Zavala-Alvarado, Nadia Benaroudj

\section{To cite this version:}

Crispin Zavala-Alvarado, Nadia Benaroudj. The Single-Step Method of RNA Purification Applied to Leptospira. Leptospira spp., 2134, Humana, pp.41-51, 2020, Methods in Molecular Biology, 978-10716-0459-5. 10.1007/978-1-0716-0459-5_5 . pasteur-02951914

\section{HAL Id: pasteur-02951914 \\ https://hal-pasteur.archives-ouvertes.fr/pasteur-02951914}

Submitted on 29 Sep 2020

HAL is a multi-disciplinary open access archive for the deposit and dissemination of scientific research documents, whether they are published or not. The documents may come from teaching and research institutions in France or abroad, or from public or private research centers.
L'archive ouverte pluridisciplinaire HAL, est destinée au dépôt et à la diffusion de documents scientifiques de niveau recherche, publiés ou non, émanant des établissements d'enseignement et de recherche français ou étrangers, des laboratoires publics ou privés.

\section{(ㄷ)(1) $\$$}

Distributed under a Creative Commons Attribution - NonCommerciall 4.0 International 
The single-step method of RNA purification applied to Leptospira

Authors: Crispin Zavala-Alvarado ${ }^{1 *} \&$ Nadia Benaroudj ${ }^{1}$

Affiliations: ${ }^{1}$ Unité de Biologie des Spirochètes, Institut Pasteur, Paris 75015, France

*Université de Paris, Sorbonne Paris Cité, COMUE BioSPC, Paris 75013, France

Corresponding authors: Nadia Benaroudj, nadia.benaroudj@pasteur.fr

Running head: Total RNA extraction from Leptospira 


\section{i. Abstract}

Establishing a rapid method to obtain pure and intact RNA molecules has revolutionized the field of RNA biology, enabling laboratories to routinely perform RNA analysis such as Northern blot, reverse transcriptase quantitative PCR and RNA sequencing. Here, we describe an application of the effective single-step method of RNA extraction (or guanidinium thiocyanate-phenol-chloroform extraction) applied to Leptospira species. This method is based on the powerful ability of guanidinium thiocyanate to inactivate RNases and on the different solubility of RNA and DNA in acidic phenol. This method allows one to reproducibly obtain total RNAs with high yield and integrity, as determined by capillary electrophoresis, suitable for the RNA sequencing technology.

ii. Key words: Spirochetes, Leptospira, RNA, Guanidinium Thiocyanate, PhenolChloroform Extraction, RIN, RNA-Seq, RT-PCR.

\section{Introduction}

Efficient acquisition of pure and intact RNA molecule is a prerequisite for numerous analytical techniques such as reverse transcriptase quantitative PCR (RT-qPCR), Northern blotting, microarray analysis, and RNA sequencing (RNA-Seq). Particularly powerful are RNA-Seq technologies that allow for profiling and quantification of RNA. Knowing which gene is expressed and how genes are regulated in a particular condition provides scientists with a comprehensive knowledge of the physiological state of cells. The pioneering transcriptomic studies performed in the 1990's have used hybridization-based microarrays technology (1). Since the development of affordable, high throughput sequencing technologies, transcriptomes are determined by RNA-Seq (2). 
Leptospira spp. are microorganisms with remarkable adaptation capacities allowing survival in different ecological niches. Pathogenic strains disseminate in the blood of infected hosts, can persist intracellularly in macrophages, colonize different animal tissues (including kidney, liver, and brain), and are shed in the environment (soil and water) through the urine of infected hosts (3). Knowledge of the molecular basis of Leptospira pathogenicity is very limited compared to other bacteria, mainly due to the lack of genetic tools available for manipulation of leptospiral genome. Inactivating a gene by allelic exchange in pathogenic Leptospira strain is feasible but very inefficient. To study the function of a given leptospiral gene, scientists usually rely on random transposon insertion mutants $(4,5)$. The transcriptomic approach is therefore instrumental not only in identifying cellular pathways involved in one particular physiological condition, but also to speculate gene function when mutants are not available. Effective RNA extraction has allowed several laboratories to perform transcriptomic studies in Leptospira, thereby leading to a better knowledge of bacterial adaptation to host osmotic stress (6), in the presence of serum (7), upon temperature changes $(8,9)$, and to the host environment $(10,11)$.

Different methods can be used to extract RNA from a biological sample. One method relies on the different solubility of cellular components in organic solvents and RNA precipitation by alcohol. Another method is based on the ability of RNA to bind to specific adsorbing material, such as silica and cellulose matrixes, and is used in most commercial RNA purification kits. In a third method, RNA is separated on density gradient centrifugation, but this method is laborious and does not allow for simultaneous processing of multiple samples. Here, we describe the method based on RNA extraction with an organic solvent and precipitation with alcohol currently applied to Leptospira strains and allowing for high yields of pure and intact RNA, compatible with the use of RNA-sequencing technology. In this protocol, harvested Leptospira are first lysed in TRIzol ${ }^{\mathrm{TM}}$. This reagent contains 
guanidinium isothiocyanate, a chaotropic agent which is very effective at inactivating endogenous RNases. It also contains low-pH phenol for separating DNA from RNA (12). After adding chloroform to the samples and subsequent centrifugation, RNAs remain in the upper clear aqueous phase while precipitated proteins and DNA remain in the interphase and lower organic phase, respectively. The RNA contained in the upper phase is transferred to a new tube and undergoes alcohol precipitation. The RNA pellet is then diluted in a suitable buffer. Traces of contaminating DNA are eliminated by DNase treatment. This guanidinium thiocyanate-phenol-chloroform extraction also known as the "single-step method" greatly improved and expedited RNA purification, and has become the gold standard widely used for any type of biological samples (13).

RNA quantification and purity can be determined by absorbance measurement at 260 and $280 \mathrm{~nm}$. A ratio $\mathrm{A}_{260} / \mathrm{A}_{280}$ of at least 1.80 indicates an acceptable purity with low protein contamination, suitable for RT-PCR. For performing RNA-Seq, RNA preparation should be of the highest quality. The integrity of RNA (i.e. absence of RNA degradation) can be assessed by analyzing the RNA preparation by capillary electrophoresis using, for instance, the chip-based device of the Agilent BioAnalyzer. This analysis will provide with a RIN (RNA Integrity Number) value that represents an objective measurement of RNA integrity ranging from 10 (highly intact RNA) to 1 (completely degraded RNA) (14). For RNA-Seq, a RIN value above 8 should be aimed.

The total RNAs obtained via this method are mostly ribosomal RNAs. Depending of the analysis method used downstream, depletion of ribosomal RNAs allowing enrichment of messenger RNAs might be necessary.

\section{Materials}


We have applied this protocol to pathogenic Leptospira (L. interrogans serovar Manilae strain L495) and saprophyte (L. biflexa serovar Patoc strain Patoc) strains cultivated in vitro in EMJH medium (see Note 1).

1. Albumin supplement: $10 \%(\mathrm{w} / \mathrm{v})$ Bovine Serum Albumin, 0.004\% (w/v) zinc sulfate, $0.015 \%(\mathrm{w} / \mathrm{v})$ magnesium chloride, $0.015 \%(\mathrm{w} / \mathrm{v})$ calcium chloride, $0.1 \%(\mathrm{w} / \mathrm{v})$ sodium pyruvate, $0.4 \%$ (w/v) Glycerol, 1.25\% (v/v) Tween 80, 0.0002\% (w/v) Vitamin B12, $0.05 \%(\mathrm{w} / \mathrm{v})$ ferrous sulfate (added at the last moment) in sterile water for injection (WFI).

2. EMJH base: dissolve $2.3 \mathrm{~g}$ of Difco Leptospira medium base EMJH (Becton Dickenson) in $900 \mathrm{ml}$ sterile WFI. Autoclave the solution.

3. EMJH medium: add $100 \mathrm{ml}$ albumin supplement to $900 \mathrm{ml}$ EMJH base. Adjust the $\mathrm{pH}$ to 7.5 and filter sterilize the solution.

4. Refrigerated centrifuge and rotor reaching $12000 \times \mathrm{g}$.

5. Water bath at $55^{\circ} \mathrm{C}$ and $4^{\circ} \mathrm{C}$.

6. Vortexer.

7. Fume hood.

8. P1000, P200, P20, P10/2 micropipettes.

9. RNase-free barrier tips for pipettes.

10. 1-2 $\mathrm{ml}$ disposable serological plastic pipettes.

11. $1.5 \mathrm{ml}$ RNase-free polypropylene microcentrifuge tubes (see Note 2).

12. 50 and $15 \mathrm{ml}$ RNase-free polypropylene conical tubes (see Note 2).

13. Surface RNase decontaminant solution.

14. TRIzol ${ }^{\mathrm{TM}}$ reagent or other commercially available guanidinium thiocyanate-acidic phenol solution (see Note 3). 


\section{Chloroform.}

16. Isopropanol.

17. $75 \%$ Ethanol in RNase-free water (see Note 4).

18. RNase-free $\mathrm{H}_{2} \mathrm{O}$.

19. DNase treatment kit (see Note 5).

20. UV Spectrophotometer.

21. Tris Acetate EDTA (TAE) running buffer (50x): $242 \mathrm{~g}$ of Tris base, $57.1 \mathrm{ml}$ of glacial acetic acid, $100 \mathrm{ml}$ of $0.5 \mathrm{M}$ EDTA, pH 8.0. Adjust the volume to 1 liter with distilled water (the $\mathrm{pH}$ should be around 8.5 ). Dilute the solution with ultrapure water to $1 \times$ for use.

22. Nucleic acid staining such as ethidium bromide (supplied in a dropper bottle at 625 $\mu \mathrm{g} / \mathrm{ml})$.

23. $1 \%$ Agarose: $1 \mathrm{~g}$ of agarose in $100 \mathrm{ml}$ of TAE running buffer. Add 1 drop (about 25 $\mu \mathrm{g} / 40 \mu \mathrm{l}$ ) of ethidium bromide in $50 \mathrm{ml}$ of the solution before agarose polymerization.

24. $6 \times$ gel loading buffer for nucleic acid: $10 \mathrm{mM}$ Tris-HCl, $\mathrm{pH}$ 7.6, 60\% glycerol, $60 \mathrm{mM}$ EDTA, $0.03 \%$ bromophenol blue, $0.03 \%$ xylene cyanol FF. Mix 1 volume of the $6 \times$ gel loading buffer with 5 volume of RNA solution (containing 0.5-1 $\mu \mathrm{g}$ of RNA).

25. Gel equipment for nucleic acid electrophoresis.

26. Electrophoresis power supply.

27. UV transilluminator to visualize nucleic acids.

\section{Methods}

Great care should be taken to prevent RNA degradation by exogenous RNases. Gloves should be worn at all times and changed frequently. People with long hair should secure it. If possible, a designated laboratory space should be reserved exclusively for RNA extraction 
and manipulation (see Note 6). All the consumable materials (tips, tubes) and solutions should be RNase-free and protected from the dust. All the non-disposable materials that will be in contact with the RNA (pipettes, benches, centrifuge, gel equipment) should be washed with a surface RNase decontaminant solution (see Note 7). All the steps are performed at room temperature unless otherwise noted.

\subsection{Cell lysis}

Optimally, the starting material should be in vitro-cultured Leptospira consisting of at least $10^{9}$ cells. This corresponds to a $30 \mathrm{ml}$ Leptospira culture at exponential phase (see Note 8).

1. Centrifuge the Leptospira cells in a $50 \mathrm{~mL}$ conical tube for $15 \mathrm{~min}$ at $3000 \times g$ at $4{ }^{\circ} \mathrm{C}$ (see Note 9).

2. Resuspend the cell pellet in $1 \mathrm{ml}$ of TRIzol ${ }^{\mathrm{TM}}$ reagent and transfer the suspension in a $1.5 \mathrm{ml}$ polypropylene tube (see Note $\mathbf{1 0}$ ).

3. Vortex well to fully resuspend the pellet.

4. Flash freeze samples in liquid nitrogen and store them at $-80^{\circ} \mathrm{C}$ until further use (see Note 11).

\subsection{RNA extraction}

1. Thaw the sample(s) at room temperature (see Note 12).

2. Add $260 \mu$ chloroform, mix thoroughly by inversion for $15 \mathrm{sec}$ and incubate for 10 $\min ($ see Note 13$)$.

3. Centrifuge for $15 \mathrm{~min}$ at $12000 \times g$ at $4{ }^{\circ} \mathrm{C}$. After the centrifugation, three phases are observed in the tube. The top clear aqueous phase contains RNA, the white ring at the interphase contains denatured precipitated proteins and the bottom pink organic phase contains DNA. 
4. Carefully, transfer the aqueous top layer containing RNA to a new clean $1.5 \mathrm{ml}$ polypropylene tube (see Note 14).

5. Add $600 \mu$ isopropanol to precipitate RNA. Mix thoroughly by gently inverting the tube. Incubate for 5-10 min at room temperature (see Note 15).

6. Centrifuge for $10 \mathrm{~min}$ at $12000 \times g$ at $4^{\circ} \mathrm{C}$ and discard the supernatant (see Note 16).

7. Wash the RNA pellet by adding $1 \mathrm{ml}$ of $75 \%$ ethanol (see Note 17).

8. Centrifuge for $5 \mathrm{~min}$ at $12000 \times g$ at $4^{\circ} \mathrm{C}$. Discard the supernatant (see Note 18).

9. Air-dry the RNA (see Note 19).

10. Resuspend the pellet in $40 \mu \mathrm{l}$ Rase-free $\mathrm{H}_{2} \mathrm{O}$ by pipetting up and down several times.

11. Incubate for $10 \mathrm{~min}$ in a water bath at $55^{\circ} \mathrm{C}$ in order to enhance the resuspension of the pellet (see Note 20).

\subsection{DNase treatment}

Here, we describe the DNase treatment using the Turbo DNA-free ${ }^{\mathrm{TM}}$ kit, but any other commercially available kit might work as well.

1. Add $5 \mu$ of the $10 \times$ Turbo DNA-free ${ }^{\mathrm{TM}}$ buffer and $4 \mu \mathrm{l}$ of RNase-free $\mathrm{H}_{2} \mathrm{O}$ (provided in the kit) to $40 \mu \mathrm{l}$ of the RNA suspension obtained in step 11 in section 3.2.

2. Add $1 \mu$ of Turbo DNA-free ${ }^{\mathrm{TM}}$ DNase (at $2 \mathrm{U} / \mu \mathrm{l}$ ). Mix by pipetting and incubate 30 min. in a water bath a $37^{\circ} \mathrm{C}$ (see Notes 20 and 21).

3. Add $5 \mu \mathrm{l}$ of DNase inactivation reagent (provided in the kit), mix well by flicking the tube to disperse the inactivating reagent, and incubate for $5 \mathrm{~min}$ at room temperature. During this incubation, flick the tube to disperse the inactivating reagent each minute in order to increase the binding of the DNase to the reagent (see Note 22). 
4. Centrifuge for $2 \mathrm{~min}$ at $10000 \times g$ and transfer the supernatant to a new clean polypropylene tube (see Note 23 ).

\subsection{Assessing quantity and quality of RNA}

The absorbance measurement at $260 \mathrm{~nm}$ allows the calculation of RNA concentration. An absorbance value of 1 corresponds to $40 \mu \mathrm{g} / \mathrm{ml}$ of RNA (for a spectrophotometer with $1 \mathrm{~cm}$ light path).

For RT-PCR, the quality of the RNA preparation can be assessed by electrophoresis on an agarose gel. When $0.5-1 \mu \mathrm{g}$ of RNA are loaded on a $1 \%$ agarose gel, three main bands can be observed, the $23 \mathrm{~S}$, the $16 \mathrm{~S}$ and the $5 \mathrm{~S}$ ribosomal RNAs (Figure 1) as the total RNA preparation contains mainly ribosomal RNAs. Messenger RNAs can be sometimes visible as faint smear.

If the RNA is to be used in RNA-Seq, the integrity of RNA should be assessed by capillary electrophoresis (see Note 24). A typical electrophoresis pattern of high-quality RNA is shown in Figure 2. In this analysis, the abundant $23 \mathrm{~S}$ and $16 \mathrm{~S}$ rRNAs are well resolved and the smaller peak corresponds to the 5S rRNA. Here, a RIN value of 9.5 was obtained, which indicates pure and non-degraded RNAs.

The yield of the purification method presented here can be up to $75 \mu \mathrm{g}$ of RNA per $10^{9}$ Leptospira and RIN values of at least 8.5 are routinely obtained, which makes RNA obtained suitable for RNA-Seq analysis.

\subsection{Storage}

RNA can be stored at $-20^{\circ} \mathrm{C}$ for a short-term storage but $-80^{\circ} \mathrm{C}$ is preferential for a long-term storage. RNA samples could be aliquoted into several tubes to minimize freeze-thaw and reduce RNase degradation occurring upon accidental RNase contamination. 


\section{Notes}

1. Only use autoclaved glassware dedicated for EMJH medium preparation. In order to avoid contaminating the glassware with components that could prevent growth of Leptospira, we rinse beforehand the glassware with sterile WFI and all the chemical stock solutions are prepared with sterile WFI.

2. You do not need to use autoclaved tubes, but tubes exclusively reserved for RNA purification and do not manipulate the tubes without wearing gloves.

3. We recommend using TRIzol ${ }^{\mathrm{TM}}$ from ThermoFisher Scientific as it has proven to work optimally with this protocol. Another equivalent commercially available reagent might work with a comparable efficiency. Alternatively, home-made solutions can be prepared (see references 12, 13 and 15) but the process is laborious.

4. Prepare the $75 \%$ Ethanol solution in a RNase-free conical tube and discard any left over.

5. We recommend using the Turbo DNA-free ${ }^{\mathrm{TM}}$ turbo kit from Invitrogen (ThermoFisher Scientific).

6. If you do not have at your disposal an exclusive designated laboratory space for RNA extraction, it might be wise to perform RNA purification when there are not too much people in the laboratory, lowering air perturbation and the risk of dust movement and contamination. Regardless, the surface and any equipment used should be cleaned with a surface decontaminant RNA/RNase removing solution. We recommend using the RNase Away from Merck.

7. If possible, we recommend having a designated pipette set and gel equipment exclusively used for RNA purification. 
8. We cultivate Leptospira in EMJH medium. It is possible to extract RNA from lower amounts of cells; however, the yield will be lower and, in our experience, working with low amounts of cells leads to a RNA preparation with a lower integrity. It is not necessary to wash the cells before adding the guanidinium thiocyanate-acidic phenol solution.

9. The cells should be rapidly processed in the guanidinium thiocyanate-acidic phenol solution $\left(\right.$ TRIzol $^{\mathrm{TM}}$ ) after harvesting them as rapid inactivation of endogenous RNases is essential for obtaining high quality RNA.

10. Manipulation of the guanidinium thiocyanate-acidic phenol solution $\left(\right.$ TRIzol $^{\mathrm{TM}}$ ) should be done under a fume hood, as the solution is highly volatile and toxic.

11. Even if RNA extraction is conducted right after cell resuspension in the guanidinium thiocyanate-acidic phenol solution (TRIzol ${ }^{\mathrm{TM}}$ ), samples should be frozen at $-80^{\circ} \mathrm{C}$ as freezing promotes cell lysis. Samples can be stored in the guanidinium thiocyanateacidic phenol solution $\left(\mathrm{TRIzol}^{\mathrm{TM}}\right)$ at $-80^{\circ} \mathrm{C}$ for at least several weeks. If you plan to analyze RNAs extracted from different biological samples, it is better to perform the RNA extraction of all samples at the same time.

12. In order to increase efficiency of cell lysis, up to three cycles of freezing/thawing can be applied to the samples. However, as promptness is key to obtain high quality RNAs, we avoid this especially when extracting RNAs for RNA-Seq.

13. This step should be performed under a fume hood as chloroform is highly volatile and toxic.

14. In order to prevent contamination with DNA and precipitated proteins, great care should be taken to avoid perturbating the three phases. It is better not to try to retrieve the totality of the upper phase to prevent carry over. 
15. You can pause at this step and store the samples in isopropanol at $-20^{\circ} \mathrm{C}$ until you are ready to proceed with the procedure, although we avoid this especially when extracting RNAs for RNA-Seq.

16. You should be able to see a white gel-like pellet containing RNA at the bottom of the tube. Great care should be taken when removing the supernatant as sometimes the RNA pellet does not tightly stick to the tube and tends to move on the tube wall.

17. You can pause at this step and store the samples in $75 \%$ ethanol at $-20^{\circ} \mathrm{C}$ until you are ready to proceed with the procedure, although we avoid this especially when extracting RNAs for RNA-Seq.

18. As washing the RNA pellet with $75 \%$ ethanol will dissolve salts contained in the pellet, the aspect of the pellet will change. Very often, the pellet becomes smaller and less visible. Again, great care should be taken when removing the supernatant. You can use a micropipette or a syringe with a $22 \mathrm{G}$ needle to remove most of the supernatant without disturbing the pellet.

19. The time for air-drying the RNA pellet will depend of the amount of ethanol left in the tube after removing the supernatant. You can put your samples under a fume hood or laminar follow cabinet to enhance the drying step. If the ethanol is properly removed, this step should take 5-10 min. You should avoid excessively drying the RNA pellet as it will decrease its solubility.

20. You should use a clean water bath. A heat block might work as well.

21. To enhance the DNase reaction, you can perform the reaction with $2 \mu \mathrm{l}(4 \mathrm{U})$ of Turbo DNA-free ${ }^{\mathrm{TM}}$ DNase. You can also perform a two-step incubation with the enzyme. In a first step, $1 \mu$ of Turbo DNA-free ${ }^{\mathrm{TM}}$ DNase are added and the sample is incubated for $30 \mathrm{~min}$ at $37^{\circ} \mathrm{C}$. Then, an additional $1 \mu$ of Turbo DNA-free ${ }^{\mathrm{TM}}$ DNase is added to the sample and the second incubation at $37^{\circ} \mathrm{C}$ is conducted for $30 \mathrm{~min}$. 
22. The amount of DNase Inactivating Reagent to be added should be adjusted depending on the number of DNase units used for the reaction. The manufacturer recommends using $5 \mu \mathrm{l}$ of DNase Inactivating Reagent for $1 \mu \mathrm{l}$ (2 unit) of DNase.

23. It might be more comfortable to perform the DNase treatment in a $0.5 \mathrm{ml}$ polypropylene tube as it will ease removal of the supernatant.

24. We recommend using the chip-based device of the Agilent BioAnalyzer as its software is the only one allowing for a RIN determination. This analysis is performed in transcriptomic facilities.

\section{References}

1. Stears RL, Martinsky T, Schena M. (2003) Trends in microarray analysis. Nat Med 9(1):140-5.

2. Wang Z, Gerstein M, Snyder M. (2009) RNA-Seq: a revolutionary tool for transcriptomics. Nat Rev Gen 10:57-63.

3. Picardeau M. (2017) Virulence of the zoonotic agent of leptospirosis: still terra incognita? Nat Rev Microbiol 15:297-307.

4. Bourhy P, Louvel H, Saint Girons I, Picardeau M. (2005) Random Insertional Mutagenesis of Leptospira interrogans, the Agent of Leptospirosis, Using a mariner Transposon. J Bacteriol 187(9):3255-3258.

5. Murray GL, Morel V, Cerqueira GM, Croda J, Srikram A, Henry R, et al. (2009) Genome-Wide Transposon Mutagenesis in Pathogenic Leptospira Species. Infect Immun 77(2):810-816.

6. Matsunaga J, Lo M, Bulach DM, Zuerner RL, Adler B, Haake DA. (2007) Response of Leptospira interrogans to physiologic osmolarity: relevance in signaling the environment-to-host transition. Infect Immun 75(6):2864-2874.

7. Patarakul K, Lo M, Adler B. (2010) Global transcriptomic response of Leptospira interrogans serovar Copenhageni upon exposure to serum. BMC Microbiol 10(1):31-46.

8. Qin J-H, Sheng Y-Y, Zhang Z-M, Shi Y-Z, He P, Hu B-Y, et al. (2006) Genomewide transcriptional analysis of temperature shift in $\mathrm{L}$. interrogans serovar lai strain 56601. BMC Microbiol 6(1):51-60.

9. Lo M, Bulach DM, Powell DR, Haake DA, Matsunaga J, Paustian ML, et al. (2006) Effects of Temperature on Gene Expression Patterns in Leptospira interrogans Serovar Lai as Assessed by Whole-Genome Microarrays. Infect Immun 74(10):5848-5859.

10. Xue F, Dong H, Wu J, Wu Z, Hu W, Sun A, et al. (2010) Transcriptional Responses of Leptospira interrogans to Host Innate Immunity: Significant Changes in Metabolism, Oxygen Tolerance, and Outer Membrane. PLOS Neg Trop Dis 4(10):e857. 
11. Caimano MJ, Sivasankaran SK, Allard A, Hurley D, Hokamp K, Grassmann AA, et al. (2014) A Model System for Studying the Transcriptomic and Physiological Changes Associated with Mammalian Host-Adaptation by Leptospira interrogans Serovar Copenhageni. PLOS Pat 10(3):e1004004.

12. Chomczynski P, Sacchi N. (1987) Single-step method of RNA isolation by acid guanidinium thiocyanate-phenol-chloroform extraction. Anal Biochem 162(1):156-159.

13. Chomczynski P, Sacchi N. (2006) The single-step method of RNA isolation by acid guanidinium thiocyanate-phenol-chloroform extraction: twenty-something years on. Nat Prot 1(2):581-585.

14. Schroeder A, Mueller O, Stocker S, Salowsky R, Leiber M, Gassmann M, et al. (2006) The RIN: an RNA integrity number for assigning integrity values to RNA measurements. BMC Mol Biol 7(1):3-16.

15. Kingston RE, Chomczynski P, Sacchi N. (1996) Guanidine Methods for Total RNA Preparation. Cur Prot Mol Biol 36(1):4.2.1-4.2.9.

\section{Figure captions}

Figure 1: Analysis of RNA preparation on agarose gel. $0.5 \mu \mathrm{g}$ of total RNAs were loaded on a $1 \%$ agarose gel in $1 \times$ TAE. Nucleic acid was stained with ethidium bromide. The bands corresponding to $23 \mathrm{~S}, 16 \mathrm{~S}$ and $5 \mathrm{~S}$ ribosomal RNA are indicated.

Figure 2: Analysis of RNA preparation by capillary electrophoresis. $0.5 \mu \mathrm{g}$ of total RNAs were analyzed on an Agilent RNA 6000 Nano chip with the 2100 Bioanalyzer. (A) Capillary electrophoresis gel-like image of the Agilent RNA 6000 ladder (lane M) and RNAs (lane RNAs). The migration position of 23S, $16 \mathrm{~S}$ and 5S rRNA is indicated at the right of the image. (B) Electropherogram trace of the RNA preparation. The peaks corresponding to different rRNAs are indicated. The RNA preparation displayed here has a RIN of 9.5. A degraded RNA preparation would display a decrease in the $23 \mathrm{~S}$ and $16 \mathrm{~S}$ rRNA signal and a concomitant increased baseline in the fast-migrating zone (before the position of the $16 \mathrm{~S}$ rRNA peak). 


\section{Acknowledgments}

Crispin Zavala-Alvarado is part of the Pasteur - Paris University (PPU) International PhD Program. Our laboratory has received funding from the European Union's Horizon 2020 research and innovation programme under the Marie Sklodowska-Curie grant agreement No 665807 and from Fondation Etchebès-Fondation de France. We would like to thanks Robert Anthony Gaultney for his suggestions on this manuscript. 